\title{
PENGARUH GAYA KEPEMIMPINAN, PEMAHAMAN GOOD GOVERNANCE, DAN KETIDAKJELASAN PERAN TEHADAP KINERJA AUDITOR PADA INSPEKTORAT PROVINSI NTB
}

\author{
Pebruwardi Hidayat' ${ }^{1}$ Endar Pituringsih ${ }^{2}$, Rr. Sri Pancawati Martiningsih ${ }^{3}$ \\ ${ }^{1}$ Master Of Acounting Program, Mataram university. E-mail.relife.hidayat@gmail.com \\ ${ }^{2}$ Faculty Of Economics and busines, Mataram University. E-mail.endar07ringsih@yahoo.co.id \\ 3Faculty Of Economics and busines, Mataram University. E-mail.pancawati@unram.ac.id
}

\begin{tabular}{|c|c|}
\hline ARTICLE INFO & ABSTRACT \\
\hline $\begin{array}{l}\text { Keywords : } \\
\text { Leadership Style, Understanding Good } \\
\text { Governance, Role Uncertainty, Auditor } \\
\text { Performance, Agency Theory, Attribution } \\
\text { Theory, Role Theory } \\
\text { Corporate governance, real earnings } \\
\text { management, Islamic banking. } \\
\text { How to cite: } \\
\text { Hidayat, P., Pituringsih, Endar., } \\
\text { Martiningsih, Rr. Sri Pancawati (2018), } \\
\text { Pengaruh Gaya Kepemimpinan, } \\
\text { Pemahaman Good Governance, Dan } \\
\text { Ketidakjelasan Peran Tehadap Kinerja } \\
\text { Auditor Pada Inspektorat Provinsi NTB. } \\
\text { JMM UNRAM, 7(4), } 47 \text { - 56 } \\
\text { DOI : } \\
\text { 10.29303/jmm.v7i4.345 }\end{array}$ & $\begin{array}{l}\text { The purposes of this study is to examine the effect of } \\
\text { leadership style, good governance understanding, and role } \\
\text { ambiguity to APIP performance at Inspectorat of West Nusa } \\
\text { Tenggara (NTB). Population of this study was the Jabatan } \\
\text { Fungsional Auditor (JFA), and Pejabat Pemeriksa Urusan } \\
\text { Pemerintah Daerah (P2UPD) in the Inspectorat of West } \\
\text { Nusa Tenggara.which amounted to } 51 \text { respondents. Data } \\
\text { were analyzed using multiple linear regression analysis. The } \\
\text { results of this study indicate that partially leadership style, } \\
\text { understanding good governance, and role ambiguity has a } \\
\text { significant effect on the performance of auditors. The } \\
\text { implication of this study is to contribute to the development } \\
\text { of science in management accounting related to agency } \\
\text { theory, attribution theory, and role theory. The next } \\
\text { implication is to provide input for the NTB Provincial } \\
\text { Inspectorate to improve auditor competency, and contribute } \\
\text { to the NTB Provincial Government in developing policies } \\
\text { related to guidance and supervision in order to maintain and } \\
\text { improve the performance of government internal auditors } \\
\text { Penelitian ini bertujuan untuk menguji pengaruh gaya } \\
\text { kepemimpinan, pemahaman good governance, dan } \\
\text { ketidakjelasan peran terhadap kinerja APIP pada Inspektorat } \\
\text { Provinsi NTB. Populasi dalam penelitian ini adalah seluruh } \\
\text { APIP yang terdapat pada Inspektorat Provinsi NTB } \\
\text { sebanyak } 51 \text { orang yang terdiri atas Jabatan Fungsional } \\
\text { Auditor (JFA) dan Pejabat Pengawas Urusan Pemerintah } \\
\text { Daerah (P2UPD). Penentuan Sampel dalam penelitian ini } \\
\text { menggunakan metode sensus. Data dianalisis menggunakan } \\
\text { analisis regresi liner berganda. Hasil penelitian ini } \\
\text { menunjukkan bahwa secara parsial gaya kepemimpinan, } \\
\text { pemahaman good governance, dan ketidakjelasan peran } \\
\text { berpengaruh signifikan terhadap kinerja auditor. Implikasi }\end{array}$ \\
\hline
\end{tabular}




\section{NATIONALLY ACCREDITED J OURNAL - DECREE NO. 21/E/KPT/2018}

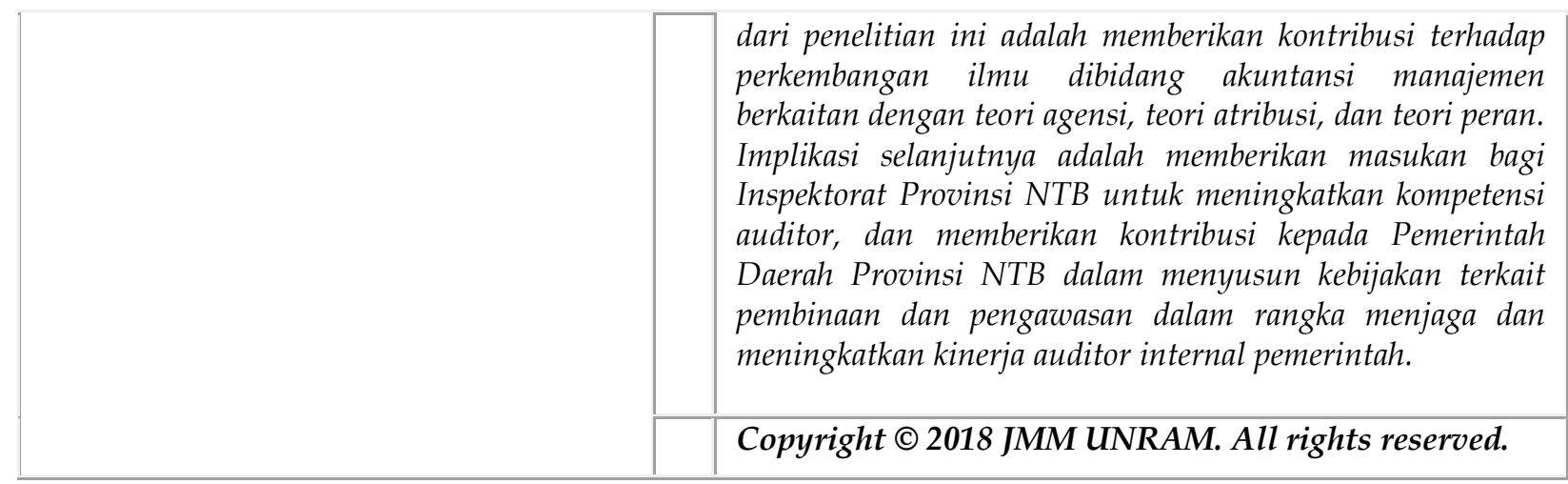

\section{PENDAHULUAN}

Auditor internal memiliki peran sangat penting dalam pelaksanaan fungsi pengawasan internal sebagai penilai kecukupan struktur pengendalian intern, penilai efektivitas, dan penilai kualitas kerja dalam rangka mewujudkan pemerintahan yang baik. Pelaksanaan pengawasan intern yang dilaksanakan oleh APIP membutuhkan dukungan dari pimpinan. Komitmen harus diawali dari pimpinan ataupun pejabat pemerintah sehingga dapat dibangun pada bawahannya. Oleh karena itu sangat dibutuhkan kepemimpinan yang efektif. Kepemimpinan yang efektif harus memberikan pengarahan terhadap usaha-usaha semua pekerja dalam mencapai tujuan-tujuan organisasi.

Keberhasilan dan kinerja seseorang auditor internal dalam melakukan pengawasan perlu menerapkan prinsip-prinsip good governance dan meningkatkan keahlian professional. Prinsi-prinsip good governance dapat menjadi acuan bagi auditor untuk menjaga efektifitas dalam pengawasan, pembinaan dan pendayagunaan aparatur negara untuk meningkatkan pencegahan dan pendeteksian terjadinya kecurangan.

Menjalankan tugas pengawasan auditor dihadapkan pada potensi ketidakjelasan peran. Ketidakjelasan peran adalah kurangnya informasi mengenai suatu peran sehingga seseorang tidak dapat melaksanakan perannya dengan baik. Kondisi ini akan berdampak pada kualitas kerja yang dihasilkan oleh auditor. Oleh karena itu, atasan harus memberikan kejelasan terhadap tugas dan tanggung jawab auditor dalam melaksanakan tugasnya.

Dukungan dari pemimpin, pemahaman good governance, dan ketidakjelasan peran akan berpengaruh terhadap kualitas kerja auditor. Kinerja baik dari auditor sebagai ujung tombak penegakan hukum dalam pelaksanaan pemerintahan sangat diperlukan. Kinerja menjadi salah satu tolak ukur yang digunakan untuk menentukan apakah suatu pekerjaan yang dilakukan oleh auditor sudah baik atau sebaliknya. Kinerja yang bak auditor akan berdampak pada terciptanya pemerintahan yang baik.

Beberapa penelitian mencoba melihat pengaruh gaya kepemimpinan, pemahaman good governance, dan ketidakjelasan peran terhadap kinerja auditor. Penelitian Wati (2010), Safitri (2014), Sitio (2014) menunjukan bahwa gaya kepemimpinan berpengaruh terhadap kinerja auditor. Sedangkan Gunawan dan Ramdan (2012), Widhi dan Setyawati (2015), Ruhbaniah (2012) menunjukkan bahwa gaya kepemimpinan tidak berpengaruh terhadap kinerja auditor internal. Wati (2010), Widhi dan Setyawati (2015), Sitio (2014) menunjukan bahwa pemahaman good governance berpengaruh terhadap kinerja auditor. Penelitian Agustina (2009) Gunawan dan ramdan (2012), Sari dan suryanawa (2016), menunjukan bahwa ketidakjelasan peran berpengaruh terhadap kinerja auditor. Fanani. Dkk (2008), 
Putra dan ariyanto (2012), Hanif (2013) menunjukan bahwa ketidakjelasan peran tidak berpengaruh secara signifikan terhadap kinerja auditor.

Hasil penelitian sebelumnya yang menguji pengaruh gaya kepemimpinan, pemahaman good governance, dan ketidakjelasan peran terhadap kinerja auditor internal masih berbeda-beda. Hasil yang berbeda dari beberapa penelitian sebelumnya mendorong peneliti untuk meneliti kembali pengaruh gaya kepemimpinan, pemahaman good governance dan ketidakjelasan peran terhadap kinerja auditor. Penelitian ini merupakan pengembangan dari penelitian sebelumnya yaitu penelitian dari Widhi dan setyawati (2015) yang berjudul Pengaruh Independensi, Gaya Kepemimpinan, Komitmen Organisasi Dan Pemahaman Good Governance Terhadap Kinerja Auditor Pemerintah (Studi Empiris Pada BPKP Perwakilan Jawa Tengah). Adapun perbedaan terletak pada variabel yang digunakan dimana pada penelitian ini menghilangkan Independensi dan Komitmen organisasi, serta menambahkan variabel Ketidakjelasan peran. Perbedaan selanjutnya pada sampel penelitian dimana penelitian sebelumnya menggunakan auditor pada BPKP Perwakilan Jawa Tengah, sedangkan penelitian ini mengambil sampel auditor baik Jabatan Fungsional Auditor (JFA) dan Pejabat Pengawas Urusan Pemerintah Daerah (P2UPD) yang bekerja di inspektorat provinsi NTB.

\section{TUJUAN PENELITIAN}

1. Untuk mengetahui pengaruh gaya kepemimpinan terhadap kinerja auditor

2. Untuk mengetahui pengaruh pemahaman good governance terhadap kinerja auditor

3. Untuk mengetahui pengaruh ketidakjelasan peran terhadap kinerja auditor

\section{TINJAUAN PUSTAKA}

\subsection{Grand Theory}

Penelitian ini menggunakan Teori Agensi, Teori Atribusi, dan Teori Peran sebagai grand teori. Teori Agensi (agency theory) adalah teori yang menggambarkan hubungan antara dua pihak dimana salah satu pihak sebagai principal menyewa atau memerintahkan pihak lain yang disebut agen untuk melaksanakan tugas atas nama principal (ross, 1973; Moe, 1984) dalam (siswanto, 2014). Teori agensi berfokus menganalisis dan mencari solusi atas masalah yang terjadi dalam hubungan agensi. Masalah yang muncul akibat adanya pendelegasian wewenang dari principal kepada agents.

Teori Atribusi mengembangkan konsep cara-cara penilaian manusia yang berbeda, bergantung pada makna yang dihubungkan dengan perilaku tertentu, karena persepsi dan penilaian terhadap manusia cukup banyak dipengaruhi oleh asumsi-asumsi yang diambil dari keadaan internal manusia tersebut. Berdasarkan teori atribusi, penyebab yang dipresepsikan dari suatu peristiwa dan bukan peristiwa actual itu sendiri yang mempengaruhi perilaku orang. Ivancevich dkk (2006) menyatakan teori atribusi teori berkaitan dengan proses dimana individu menginterpretasikan bahwa peristiwa disekitar mereka disebabkan oleh bagian lingkungan mereka yang secara relatif stabil.

Menurut Kahn (1964) dalam Agustina (2009) teori peran adalah pemahaman mendalam terhadap sifat individu untuk memahami perilaku yang tepat pada posisi yang dimiliki dalam kehidupan bermasyarakat sebagai pelaku sosial. Peran mencerminkan posisi seseorang dalam sistem sosial dengan hak dan kewajiban, kekuasaan dan tanggung jawab yang menyertainya. Untuk dapat berinteraksi satu sama lain, orang-orang memerlukan cara tertentu guna mengantisipasi perilaku orang lain 


\subsection{Kinerja Aparat Pengawas Intern Pemerintah (APIP)}

Kinerja didefinisikan sebagai evaluasi terhadap pekerjaan yang dilakukan melalui atasan langsung, rekan kerja, diri sendiri dan bawahan langsung (Kalbers \& Fogarty, 1995). Mulyono (2009) menjelaskan kinerja APIP merupakan kualitas dan kuantitas dari suatu hasil kerja (output) individu maupun kelompok dalam suatu aktivitas tertentu yang diakibatkan oleh kemampuan alami atau kemampuan yang diperoleh dari proses belajar serta keinginan untuk berprestasi lebih baik. Kinerja (prestasi kerja) dapat diukur melalui pengukuran tertentu (standar), dimana kualitas adalah berkaitan dengan mutu kerja yang dihasilkan, sedangkan kuantitas adalah jumlah hasil kerja yang dihasilkan dalam kurun waktu tertentu, dan ketepatan waktu adalah kesesuaian waktu yang telah direncanakan (Trisnaningsih, 2007).

\subsection{Gaya kepemimpinan}

Gaya kepemimpinan (leadership style) merupakan cara pimpinan untuk mempengaruhi orang lain atau bawahannya sedemikian rupa sehingga orang tersebut mau melakukan kehendak pimpinan untuk mencapai tujuan organisasi meskipun secara pribadi hal tersebut mungkin tidak disenangi (Luthans, 2002:575). Gaya kepemimpinan merupakan suatu proses mempengaruhi dan mengarahkan perilaku orang lain, baik individu maupun kelompok untuk mencapai tujuan tertentu, Heidjrachman dan Husnan (2002). Effendi (1992) mendefinisikan bahwa gaya kepemimpinan adalah cara seorang pemimpin melaksanakan kegiatannya dalam upaya membimbing, memandu, mengarahkan, dan mengontrol pikiran, perasaan, atau prilaku seseorang atau sejumlah orang untuk mencapai tujuan tertentu

\subsection{Pemahaman Good Governance}

Pemahaman atas good governance adalah untuk menciptakan keunggulan manajemen kinerja baik pada perusahaan bisnis manufaktur (good corporate governance) ataupun perusahaan jasa, serta lembaga pelayanan publik atau pemerintahan (good government governance), Sapariyah (2011). Pemahaman good governance merupakan wujud penerimaan akan pentingnya suatu perangkat peraturan atau tata kelola yang baik untuk mengatur hubungan, fungsi dan kepentingan berbagai pihak dalam urusan bisnis maupun pelayanan publik. Pemahaman atas good governance adalah untuk menciptakan keunggulan organisasi kinerja baik pada perusahaan bisnis manufaktur (good corporate governance) ataupun perusahaan jasa, serta lembaga pelayanan publik/pemerintahan (good government governance).

\subsection{Ketidakjelasan Peran}

Ketidakjelasan peran muncul dalam lingkungan kerja saat seorang karyawan tidak memiliki informasi yang memadai untuk menghasilkan kinerja yang efektif dari peran yang diberikan (Senatra, 1980). Ramadhan (2011) dalam Rosaly (2015) menyatakan "Seseorang dapat mengalamai ketidakjelasan peran jika merasa tidak ada kejelasan sehubungan dengan ekspektasi pekerjaan karena kurangnya informasi untuk penyelesaian pekerjaan atau untuk menjelaskan deskripsi tugas dan pekerjaan. Berdasarkan pendapat mengenai ketidakjelasan peran diatas, bisa dapat diambil kesimpulan bahwa ketidakjelasan peran merupakan kondisi psikologis yang dialami oleh auditor, dimana auditor merasa tidak tercukupinya respon lingkungan atas hasil pekerjaan yang dilakukan maupun tidak terpenuhinya harapan auditor atas informasi yang dibutuhkan untuk melaksanakan pekerjaan. 


\subsection{Kerangka Penelitian}

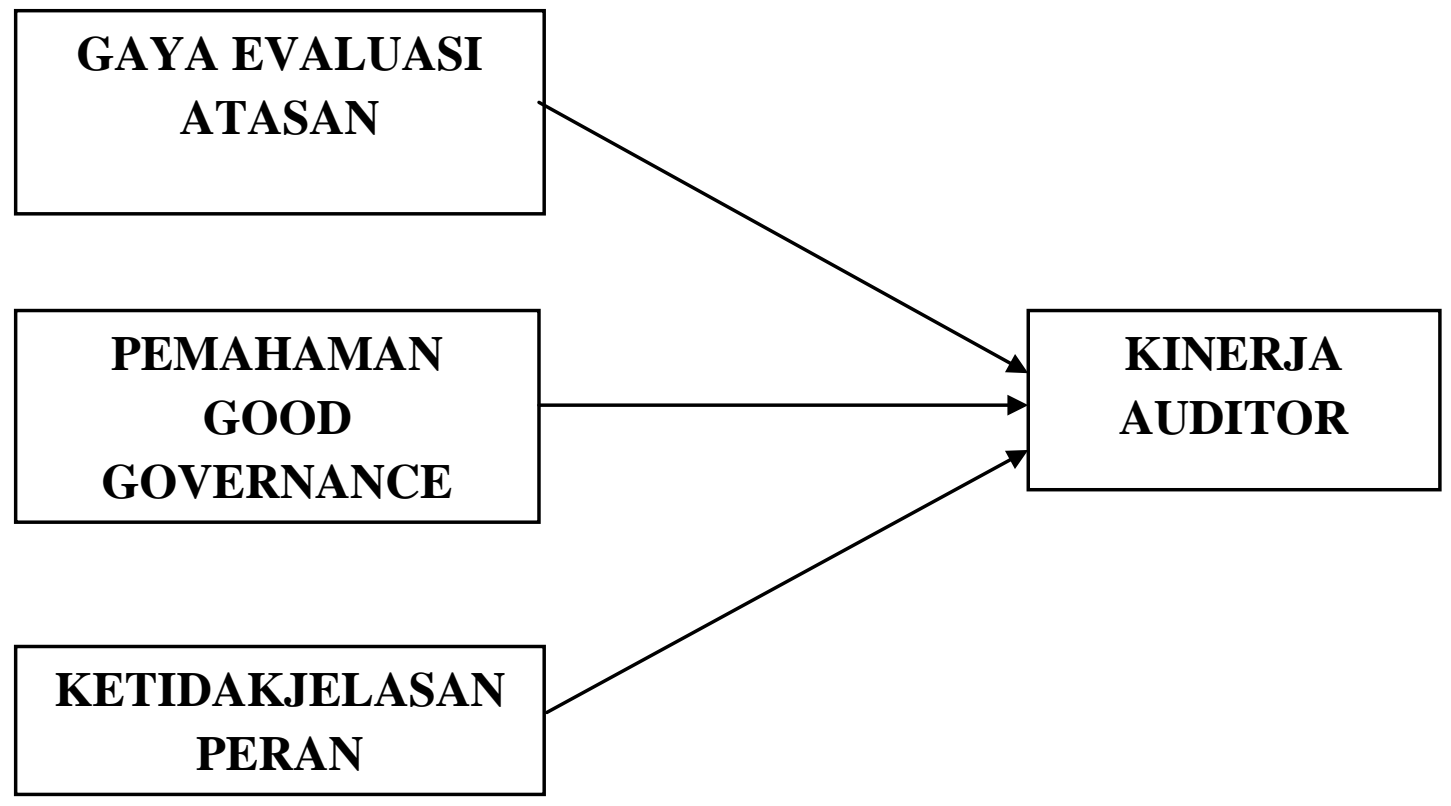

\section{METODE PENELITIAN}

\subsection{Jenis penelitian}

Jenis penelitian ini adalah penelitian asosiatif. Penelitian asosiatif adalah yaitu adalah penelitian yang bertujuan untuk mengetahui hubungan dua variabel atau lebih. (Sugiyono,2014:55). Penelitian ini bermaksud menguji variabel independen (pengaruh gaya kepemimpinan, pemahaman good governance, ketidakjelasan peran), terhadap variabel dependen (kinerja auditor)

Populasi dari penelitian ini auditor internal yang bekerja pada Inspektorat Provinsi Nusa Tenggara Barat. Seluruh populasi dijadikan responden dalam penelitian dengan metode sensus. Responden dalam penilitian ini adalah semua auditor internal yang bekerja di Inspektorat Provinsi NTB. Auditor internal ini meliputi Jabatan Fungsional Auditor (JFA) dan Pejabat Pengawas Urusan Pemerintah Daerah (P2UPD) yang terdapat di Inspektorat Provinsi NTB. Metode pengambilan data menggunakan metode sensus. Metode sensus digunakan karena adanya keterbatasan sampel penelitian. Adapun jumlah Jabatan Fungsional Auditor (JFA) dan Pejabat Pengawas Urusan Pemerintah Daerah (P2UPD) yang terdapat di Inspektorat Provinsi NTB sejumlah 51 orang dengan rincian seperti pada tabel 3.1

Tabel 3.1 Data Jumlah JFA dan P2UPD pada Inspektorat Provinsi NTB

\begin{tabular}{|l|l|c|}
\hline No & Nama Jabatan & Jumlah \\
\hline 1 & Jabatan Fungsional Auditor (JFA) & 32 \\
\hline 2 & Pejabat Pengawas Urusan Pemerintah Daerah (P2UPD) & 19 \\
\hline
\end{tabular}




\section{PEMBAHASAN}

\subsection{Hasil Uji Parsial dan Simultan}

Hasil uji secara parsial dengan menggunakan uji t maupun Uji secara simultan (Uji F) dapat dilihat pada Tabel 2 di bawah ini.

\begin{tabular}{lcccc}
\hline Variabel & Beta & T & Sig & Keterangan \\
\hline Constant & 1,865 & 0,506 & 0,615 & - \\
Gaya Kepemimpinan & 0,299 & 2,203 & 0,033 & Diterima \\
Pemahaman Good Governance & 0,250 & 2,286 & 0,027 & Diterima \\
Ketidakejlasan Peran & 0,482 & 2,430 & 0,019 & Diterima \\
\hline
\end{tabular}

\begin{tabular}{llr} 
A & $:$ & $5 \%$ \\
Adjusted R Square & $:$ & 0,538 \\
F hitung & $:$ & 20,027 \\
Sig F & $:$ & 0,000 \\
\hline
\end{tabular}

Tabel 2 di atas menunjukan bahwa 1) Gaya Kepemimpinan yaitu berpengaruh terhadap Kinerja Auditor, ternyata hasil temuannya menunjukan bahwa Gaya Kepemimpinan (X1) berpengaruh terhadap Kinerja Auditor pada tingkat signifikansi 0,033 $(\mathrm{P}<0,05)$, sehingga hipotesis diterima. Hal ini dibuktikan dengan besarnya regresi $(\beta)$ yaitu 0,299 dan $t$ hitung sebesar 2,203 serta probabilitas sebesar 0,033(p>0,05); 2) Pemahaman Good Governance yaitu berpengaruh terhadap Kinerja Auditor, ternyata hasil temuannya menunjukan bahwa Pemahaman Good Governance (X2) berpengaruh terhadap Kinerja Auditor pada tingkat signifikansi 0,027 $(\mathrm{P}<0,05)$, sehingga hipotesis diterima. Hasil ini dibuktikan dengan besarnya regresi $(\beta)$ yaitu 0,250 dan $t$ hitung sebesar 2,286 serta probabilitas sebesar 0,027 ( $<<0,05)$; 3) Ketidakjelasan Peran yaitu berpengaruh terhadap Kinerja Auditor, ternyata hasil temuannya menunjukan bahwa Ketidakjelasan Peran (X3) berpengaruh terhadap Kinerja Auditor pada tingkat signifikansi 0,019 $(\mathrm{P}<0,05)$, sehingga hipotesis diterima. Hasil ini dibuktikan dengan besarnya regresi $(\beta)$ yaitu 0,482 dan $t$ hitung sebesar 2,430 serta probabilitas sebesar 0,019 $(\mathrm{p}<0,05)$

Sementara itu, hasil uji secara simultan dengan menggunakan uji $\mathrm{F}$ pada tabel di atas menunjukkan nilai $\mathrm{F}$ hitung adalah 20,027 dengan angka probabilitas sebesar 0,000 $(p<0,05)$ sehingga hipotesis yang mengatakan terdapat pengaruh signifikan Gaya kepemimpinan, Pemahaman Good Governance, dan Ketidakjelasan Peran secara simultan Terhadap Kinerja Auditor pada Inspektorat Provinsi NTB telah memenuhi kriteria diterima. Sehubungan hasil analisis regresi berganda yang ditampilkan pada tabel 2 di atas maka dapat dihasilkan persamaan regresi sebagai berikut:

$$
\mathrm{Y}=1,865+0,299 \mathrm{X} 1+0,250 \mathrm{X} 2+0,482 \mathrm{X} 3+\mathrm{e}
$$

Berdasarkan hasil analisis regresi berganda dengan menggunakan uji $F$ menunjukkan gaya kepemimpinan, pemahaman good governance, dan ketidakjelasan peran berpengaruh secara simultan terhadap kinerja auditor internal pada Inspektorat provinsi NTB. hal tersebut ditunjukkan oleh nilai probabilitas sebesar $0,000(p<0,05)$. Secara parsial hasil uji t menunjukkan bahwa gaya kepemimpinan, pemahaman good governance, dan ketidakjelasan peran berpengaruh terhadap kinerja auditor internal. Hal ini menunjukkan bahwa gaya kepemimpinan yang baik, pemahaman yang baik terhadap prinsip-prinsip good governance, dan kejelasan peran dalam melaksanakan tugas akan meningkatkan kinerja auditor internal pada inspektorat provinsi NTB. 


\subsection{Pengaruh gaya kepemimpinan terhadap kinerja auditor internal}

Hasil analisis data dalam penelitian ini, menunjukan bahwa gaya kepemimpinan berpengaruh secara signifikan terhadap kinerja auditor. Kondisi ini ditunjukkan sesuai dengan data pada tabel 2, dimana nilai $t$ hitung yang diperoleh lebih besar nilai $t$ tabel dengan tingkat signifikansi yang berada di bawah 0,05. Hal ini berarti bahwa secara statistik, variabel gaya kepemimpinan pada Inspektorat Provinsi NTB berpengaruh signifikan terhadap kinerja auditor. Selain itu, koefisien variabel gaya kepemimpinan sebesar 0,2991 mengandung makna bahwa perubahan satu satuan gaya kepemimpinan akan meningkatkan kinerja auditor intern pemerintah sebesar 0,299 satuan.

Berdasarkan hasil analisis regresi dapat disimpulkan bahwa gaya kepemimpinan yang mencakup gaya kepemimpinan berorientasi tugas dan kepemimpinan berbasis hubungan (konsiderasi) yang diterapkan oleh pimpinan instansi pada Inspektorat Provinsi NTB sudah sesuai dengan ekspektasi para auditor internal pada Inspektorat Provinsi NTB. hal ini ditunjukkan dengan jawaban responden terhadap pertanyaan didominasi oleh jawaban setuju dan sangat setuju. Dengan demikian, gaya kepemimpinan yang dilaksanakan pimpinan Inspektorat Provinsi NTB saat ini perlu dipertahankan dan dikembangkan untuk kedepannya.. Kesesuaian ekspektasi auditor internal terhadap gaya kepemimpinan yang dijalankan pimpinan instansi akan mempengaruhi kinerja auditor internal dalam menjalankan tugas. Pada akhirnya akan meningkatkan kinerja pimpinan instansi serta akan berdampak pada efektifitas pengelolaan keuangan daerah secara tidak langsung.

\subsection{Pengaruh pemahaman good governance terhadap kinerja auditor internal}

Hasil analisis data dalam penelitian ini, menunjukan bahwa pemahaman good governancee berpengaruh secara signifikan terhadap kinerja auditor. Kondisi ini ditunjukkan sesuai dengan data pada tabel 2, dimana nilai t hitung yang diperoleh lebih besar dari nilai $t$ tabel dengan tingkat signifikansi yang berada di bawah 0,05. Hal ini berarti bahwa secara statistik, variabel pemahaman good goernance pada Inspektorat Provinsi NTB berpengaruh signifikan terhadap kinerja auditor. Selain itu, koefisien variabel pemahaman good governance sebesar 0,250 mengandung makna bahwa perubahan satu satuan pemahaman good governance akan meningkatkan kinerja auditor intern pemerintah sebesar 0,250 satuan.

Berdasarkan hasil analisis regresi dapat disimpulkan bahwa pemahaman good governance yang mencakup: prinsip keadilan, transparansi, akuntabilitas, dan pertanggung jawaban sudah difahami dengan baik oleh auditor internal Inspektorat Provinsi NTB sehingga berpengaruh terhadap kinerja auditor internal. Hal tersebut dapat dibuktikan dengan jawaban responden yang sebagian besar menjawab setuju dan sangat setuju. Dengan demikian, pemahaman yang dimiliki auditor internal tentang prinsip-prinsip good governance harus tetap dijaga dan tingkatkan kualitasnya. Peningkatkan kualitas dapat dilakukan dengan pemberian pelatihan secara berkelanjutan tentang prinsip-prinsip good governance. Adanya pemahaman yang baik serta aplikasinya dalam menjalankan tugas sebagai auditor akan berdampak pada meningkatnya kinerja auditor internal.

\subsection{Pengaruh ketidakjelasan peran terhadap kinerja auditor internal}

Hasil analisis data dalam penelitian ini, menunjukan bahwa ketidakjelasan peran berpengaruh secara signifikan terhadap kinerja auditor. Kondisi ini ditunjukkan sesuai dengan data pada tabel 2 , dimana nilai $t$ hitung yang diperoleh berada di atas nilai $t$ tabel dengan tingkat signifikansi yang berada di bawah 0,05. Hal ini berarti bahwa secara 


\section{NATIONALLY ACCREDITED J OURNAL - DECREE NO. 21/E/KPT/2018}

statistik, variabel ketidakjelasan peran pada Inspektorat Provinsi NTB berpengaruh signifikan terhadap kinerja auditor. Selain itu, koefisien variabel ketidakjelasan peran sebesar 0,482 mengandung makna bahwa perubahan satu satuan gaya kepemimpinan akan meningkatkan kinerja auditor intern pemerintah sebesar 0,482 satuan.

Berdasarkan hasil analisis regresi dapat disimpulkan bahwa variabel ketidakjelasan peran yang meliputi pengetahuan mengenai arah dan kebijakan organisasi, dan pengetahuan mengenai tanggung jawab dan wewenang, dan jabatan berpengaruh terhadap kinerja auditor internal. hal tersebut dapat dibuktikan dengan jawaban responden yang sebagian bersar menjawab dengan jawaban setuju dan sangat setuju. Dengan demikian, kejelasan tugas dan tanggung jawab auditor internal membuat auditor internal mudah dalam melaksanakan tugas pengawasan dan pembinaan. Kemudahan dalam menjalankan tugas berdampak pada kualitas kerja auditor internal baik secara kualitas maupun kuantitas.

\section{KESIMPULAN DAN SARAN}

\subsection{Kesimpulan}

Berdasarkan hasil pengolahan data, kesimpulan dalam penelitian ini adalah:

1. Gaya Kepemimpinan berpengaruh positif terhadap Kinerja Auditor Internal pada Inspektorat provinsi NTB.

2. Pemahaman Good Governance berpengaruh positif terhadap kinerja Auditor Internal pada Inspektorat Provinsi NTB.

3. Ketidakjelasan Peran berpengaruh positif terhadap Kinerja Auditor Internal pada Inspektorat Provinsi NTB.

\subsection{Saran}

Saran yang dapat dirumuskan dalam penelitian ini adalah sebagai berikut:

1. Penelitian selanjutnya yang akan mengembangkan hasil penelitian ini disarankan untuk memperluas ruang lingkup penelitian menjadi Inspekorat se-Provinsi NTB agar hasil yang diperoleh lebih menggambarkan realitas di lapangan dan lebih mendalam terkait kinerja auditor internal.

2. Penelitian selanjutnya diharapkan dapat mengembangkan variabel penelitian dengan menggunakan variabel lain sebagai variabel independen seperti variabel independensi dan komitmen organisasi.

3. Penelitian selanjutnya diharapkan dapat mengembangkan dan mencari referensi yang lebih banyak terkait intrumen penelitian, agar lebih mengambarkan hal-hal yang berpengaruh terhadap kemampuan kinerja auditor.

\section{DAFTAR PUSTAKA}

Agustina, Lidya. (2009). Pengaruh Konflik Peran, Ketidakjelasan Peran, dan Kelebihan Peran terhadap Kepuasan Kerja dan Kinerja Auditor (Penelitian pada Kantor Akuntan Publik yang Bermitra Dengan Kantor Akuntan Publik Big Four di Wilayah DKI Jakarta). Jurnal Akuntansi Vol.1 No.1 Mei 2009: 40-69

Effendi, Onong U. (1992). Kepemimpinan dan Komunikasi. Jakarta: Mandar Maju

Fanani, Zaenal. Dkk. (2008). Pengaruh Struktur Audit, Konflik Peran, Dan Ketidakjelasan Peran Terhadap Kinerja Auditor. Jumal Akuntansi dan Keuangan Indonesia Volume 5 - Nomor 2, 
Gibson, J. L, Ivancevich John M dan Donnely James H, Jr. (1996). Organisasi: Perilaku, Struktur dan Proses. Terjemahan.Jilid 1. Penerbit Binarupa Aksara, Jakarta.

Gunawan Hendra dan Z. Ramdan. (2012). Pengaruh Konflik Peran, Ketidakjelasan Peran, Kelebihan Peran Dan Gaya Kepemimpinan Terhadap Kinerja Auditor Di KAP Wilayah DKI Jakarta.Jurnal Binus Business Review, 3(2).

Hanif, Rheny Afriana. (2013)."Pengaruh Struktur Audit, Konflik Peran, Dan Ketidakjelasan Peran Terhadap Kinerja Auditor". Jurnal Ekonomi Volume 21, Nomor 3 September 2013

Heidjrachman dan Suad, Husnan. (2002). Manajemen Personalia. Yogyakarta: Badan Penerbit Fakultas Ekonomi (BPFE)

Ivancevich dkk (2006). Prilaku Dan Manajemen Organisasi. Surabya: Erlangga

Kalbers, L.P., \& Fogarty, T.J. (1995). Profesionalism \& its Consequences: A Study of Internal Auditors. Auditing: A Journal of Practice \& Theory, 14: 64-86.

Luthans, Fred. (2002). Organizational Behavior. ninth Edition. McGraw-Hill. Inc., New York

Mulyono, Agus. (2009). Analisis faktorfaktor kopetensi aparatur Inspektorat dan Pengaruhnya terhadap kinerja inspektorat kabupaten Deli Serdang. Tesis.Universitas Sumatera Utara

Putra, I Gede Bandar Wira dan Dodik Ariyanto. (2012). Pengaruh Independensi, profesionalisme, Struktur Audit, Dan Role Stress Terhadap Kinerja Auditor Bpk Ri Perwakilan Provinsi Bali. Universitas Udayana

Rosally, Catherina dan Yulius Jogi. (2015). Pengaruh Konflik Peran, Ketidakjelasan Peran, Dan Komitmen Organisasi Terhadap Kinerja Audito. Publication.petra.ac.id

Ruhbaniah, Aluh. (2012). Determinan Kinerja Auditor Internal Pada Inspektorat Se-Pulau Lombok. Jurnal Ekonomi dan Keuangan. Jurnal Ekonomi dan Keuangan

Safitri, Devi. (2014). Pengaruh Independensi Auditor Dan Gaya Kepemimpinan Terhadap Kinerja Auditor Dengan Komitmen Organisasi Sebagai Variabel Intervening (Studi Empiris : Kantor Akuntan Publik Pekanbaru, Batam, Dan Medan. Jurnal Ilmiah Ekonomi dan Bisnis Vol. 11, No.2

Sapariyah, Rina Ani. (2011). Pengaruh Good Governance dan Independensi Auditor Terhadap Kinerja Auditor dan Komitmen Organisasi (Survey pada Kantor Akuntan Publik di Surakarta). Jurnal Ekonomi Bisnis dan Perbankan. Vol. 19, No. 16.

Sari, Ni Putu Eka Ratna dan I Ketut Suryanawa. (2016). Konflik Peran, Ketidakjelasan Peran, Dan Kelebihan Peran Terhadap Kinerja Auditor Dengan Tekanan Waktu Sebagai Pemoderasi. ojs.unud.ac.id

Sedarmayanti., (2007). Good Governance dan Good Corporate Governance. Bagian Ketiga. CV. Mandar Maju

Senatra, P.T. (1980). Role Conflict Role Amiguity, and Organizational Climate in a Public Accounting Firm. The Accounting Review. Vol. 5, No. 4

Sitio, Ristina. (2014). Pengaruh Pemahaman Good Governance, Gaya Kepemimpinan, Budaya Organisasi Dan Struktur Audit Terhadap Kinerja Auditor (Studi Empiris Pada Kantor Akuntan Publik Di Kota Semarang. Accounting Analisis Journal

Trisnaningsih, Sri. 2007. “Independensi Auditor dan Komitmen Organisasi sebagai Mediasi Pengaruh Pemahaman Good Governance, Gaya Kepemimpinan dan Budaya Organisasi Terhadap Kinerja Auditor". Jurnal Simposium Nasional Akuntansi X Makassar 


\section{NATIONALLY ACCREDITED J OURNAL - DECREE NO. 21/E/KPT/2018}

Wahyulina, sri. (2015). Pengaruh Gaya Kepemimpinan, Reward, Punishment, dan Sistem Pengendalian Intern Terhadap Penerapan Anggaran Berbasis Kinerja pada Badan Layanan Umum Universitas Mataram. Tesis Universitas Mataram

Wati Elya. (2010). Pengaruh independensi, gaya kepemimpinan, komitmen organisasi, dan pemahaman good governance terhadap kinerja auditor pemerintah (studi pada auditor pemerintah di BPKP perwakilan bengkulu. SNA XIII Purwokerto

Wibowo, Leo Ori. (2015). Pengaruh Pemahaman sistem Informasi Akuntansi Keuangan Daerah, Kompetensi, Dan Motivasi Auditor Terhadap Kinerja Auditor. Tesis Universitas Mataram

Widhi, Saputro Nugroho dan Dr. Erma Setyawati, Ak, M.M., (2015). " Pengaruh Independensi, Gaya Kepemimpinan, Komitmen Organisasi Dan Pemahaman Good Governance Terhadap Kinerja Auditor Pemerintah ( Studi Empiris Pada Bpkp Perwakilan Jawa Tengah . Jurnal Manajemen dan Bisnis Volume 19, Nomor 1, Juni 2015, hlm 64-79

Winidiantari, Putu Nita dan Ni Luh Sari Widhiyani. (2015) ."Pengaruh Konflik Peran, Ketidakjelasan Peran, Struktur Audit, Motivasi Dan Kepuasan Kerja Pada Kinerja Auditor" 